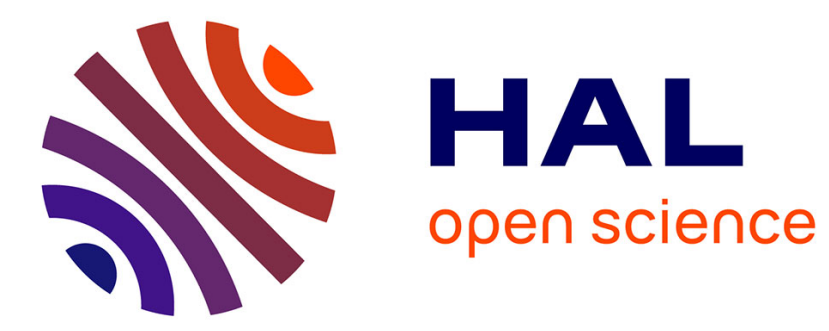

\title{
Gold nanoparticles and oxidative stress in
}

\author{
S. Tedesco, H. Doyle, G. Redmond, D. Sheehan
}

\section{To cite this version:}

S. Tedesco, H. Doyle, G. Redmond, D. Sheehan. Gold nanoparticles and oxidative stress in. Marine Environmental Research, 2008, 66 (1), pp.131. 10.1016/j.marenvres.2008.02.044 . hal-00501953

\section{HAL Id: hal-00501953 https://hal.science/hal-00501953}

Submitted on 13 Jul 2010

HAL is a multi-disciplinary open access archive for the deposit and dissemination of scientific research documents, whether they are published or not. The documents may come from teaching and research institutions in France or abroad, or from public or private research centers.
L'archive ouverte pluridisciplinaire HAL, est destinée au dépôt et à la diffusion de documents scientifiques de niveau recherche, publiés ou non, émanant des établissements d'enseignement et de recherche français ou étrangers, des laboratoires publics ou privés. 


\section{Accepted Manuscript}

Gold nanoparticles and oxidative stress in Mytilus edulis

S. Tedesco, H. Doyle, G. Redmond, D. Sheehan

PII:

S0141-1136(08)00049-4

DOI:

10.1016/j.marenvres.2008.02.044

Reference:

MERE 3201

To appear in:

Marine Environmental Research

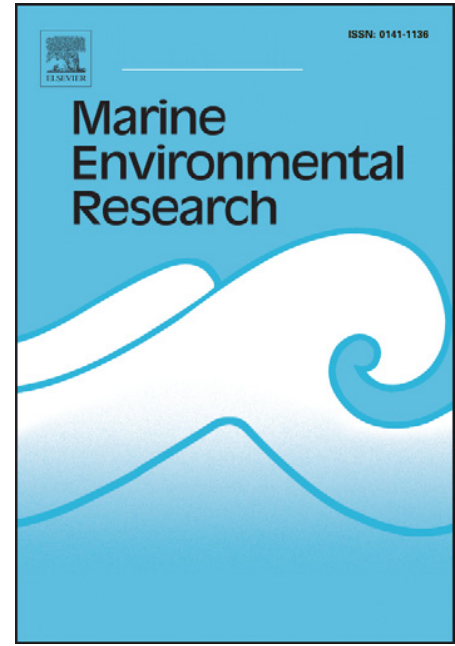

Please cite this article as: Tedesco, S., Doyle, H., Redmond, G., Sheehan, D., Gold nanoparticles and oxidative stress in Mytilus edulis, Marine Environmental Research (2008), doi: 10.1016/j.marenvres.2008.02.044

This is a PDF file of an unedited manuscript that has been accepted for publication. As a service to our customers we are providing this early version of the manuscript. The manuscript will undergo copyediting, typesetting, and review of the resulting proof before it is published in its final form. Please note that during the production process errors may be discovered which could affect the content, and all legal disclaimers that apply to the journal pertain. 


\title{
Gold nanoparticles and oxidative stress in Mytilus edulis
}

\author{
S. Tedesco ${ }^{\text {a }}$, H. Doyle ${ }^{b}$, G. Redmond ${ }^{\text {b }}$, D. Sheehan ${ }^{\text {a,* }}$ \\ ${ }^{a}$ Proteomics Research Group, Department of Biochemistry, Environmental Research Institute, University \\ College Cork, Cork, Ireland \\ ${ }^{b}$ Nanotechnology Research Group, Tyndall National Institute, Cork, Ireland
}

\begin{abstract}
Little is known about potential environmental impact of nanoparticles. Gold nanoparticles can cause unexpected biological responses. Here, Mytilus edulis were exposed (24h) to gold-citrate nanoparticles (GNP), menadione and both compounds simultaneously (GNP/menadione). Protein ubiquitination and carbonylation were determined in gill, mantle and digestive gland, along with traditional oxidative stress biomarkers; catalase activity and neutral red retention time assay (haemolymph). 2DE gels were performed on gill proteins (menadione; GNP/menadione). Our results reveal that GNP may induce oxidative stress.
\end{abstract}

Keywords: Carbonylation; Ubiquitin; Oxidative stress; Proteomics; Mytilus edulis; Gold nanoparticles.

* Corresponding author. Tel + 35321 4904207; fax: +353214274034.

E-mail address: d.sheehan@ucc.ie (D. Sheehan) 
Nanoparticles (NP) have diameter $\sim 1-100 \mathrm{~nm}$ with properties differing from corresponding macroparticles due to increased numbers of surface-exposed atoms (Moore, 2006). They modify cellular uptake, protein binding and transport and access normally inaccessible sites (Nel et al., 2006). Thus, they are potential threats to aquatic organisms (Moore, 2006).

Biological effects of NP depend on chemical composition and size. Gold NP (GNP) physicochemical properties depend on oxidation state (-I to V) with only gold 0 , I, and III being biologically stable. Protein Amino/thiol groups strongly bind GNP (Casas et al., 2006). GNP ( $1 \mathrm{~nm}$ diameter) can penetrate cell/nuclear membranes, attaching to DNA (Tsoli et al., 2005) while, at diameter $\sim 18 \mathrm{~nm}$, NP penetrated cells but gave no toxicity (Connor et al., 2005).

Little is known about the uptake of NPs in aquatic organisms which led us to investigate GNP effects in Mytilus edulis, a filter-feeder. To determine possible toxicity, we measured protein ubiquitination and carbonylation and more traditional biomarkers (catalase activity, lysosomal membrane stability). Ubiquitination increases in acute oxidative stress (OS) in bivalves while protein side-chains are modified to aldehyde/ketone groups (carbonylation) by OS (McDonagh and Sheehan, 2006).

M. edulis, ( 4-7 cm length) were sampled from a clean site in Cork Harbour, Ireland (McDonagh and Sheehan, 2006). Four groups $(\mathrm{n}=50)$ were held in tanks (1 week, $12 \mathrm{~h}$ light/dark cycle, $34-36 \%$ salinity and $\left.15-16{ }^{\circ} \mathrm{C}\right)$ with feeding and water changing (48h intervals; Phytoplex ${ }^{\mathrm{TM}}$ phytoplankton feed, Kent Marine Inc., Acworth, GA, USA). They were exposed $(24 \mathrm{~h})$ to: $750 \mathrm{ppb}$ gold-citrate nanoparticles (GNP, gold 0, 13nm); 1mM menadione; $750 \mathrm{ppb}$ GNP plus $1 \mathrm{mM}$ menadione. Controls were treated identically. Both 1 
mM menadione (McDonagh and Sheehan, 2006) and 750 ppb NP fullerene (Zhu et al., 2006) cause OS.

Digestive gland, gill and mantle tissues were dissected, pooled (groups of 5 animals), frozen (liquid nitrogen) and stored $\left(-70^{\circ} \mathrm{C}\right)$. They were homogenized $(10 \mathrm{mM}$ Tris/HCl, $\mathrm{pH}$ 7.2, 500mM sucrose, 1mM EDTA, 1mM PMSF), centrifuged at 20,000g $\left(1 \mathrm{~h}, 4^{\circ} \mathrm{C}\right)$ and stored $\left(-70^{\circ} \mathrm{C}\right)$. These were used for all analyses except measurement of lysosomal membrane stability which was determined in fresh haemolymph (12 mussels) by neutral red retention time (NRRT; Lowe et al., 1995). Granular haematocytes were observed every 15 min under light microscopy $(100 \mathrm{X})$. NRRT was when $50 \%$ counted cells presented red cytosol. Catalase activity (CAT, EC 1.11.1.6) was measured as a decrease in $\mathrm{A}_{240}\left(\varepsilon=-0.04 \mathrm{mM}^{-1} \mathrm{~cm}^{-1}\right.$; Claiborne, 1985). Protein was determined with bovine serum albumin (BSA) as a standard (Bradford, 1976). One-dimensional SDS-PAGE (1DE; 12\% gels) was performed on equal amounts of protein from each tissue, loaded in 12 wells ( 3 samples per treatment). Proteins were then transferred to $0.2 \mu \mathrm{m}$ nitrocellulose membranes (ProTran, Schleicher \& Schuell, Dasel, Germany) and blocked with $1 \%$ BSA in 10mM PBS, pH 7.4, with $0.01 \%$ Tween 20 (PBS-T) overnight at $4^{\circ} \mathrm{C}$. Ubiquitination was determined on membranes incubated with antiubiquitin, visualized by chemiluminescence and scanned (GS-800 scanner, Bio-Rad Laboratories) (McDonagh and Sheehan, 2006). Membranes stained with 0.2\% Ponceau S in acetic acid were similarly scanned. Total intensity of all bands from the same blot, were quantified (arbitrary units, A.U.; Quantity One image analysis software, Bio-Rad, Hercules, CA, USA). Total optical densities for each lane were normalised with those from Ponceau staining from the same blot. Carbonylated samples derivatized with 2, 4-dinitrophenyl (DNP)hydrazine were probed with anti-DNP (DakoCytomation) and scanned as above (McDonagh and Sheehan, 2006). Two dimensional electrophoresis (2DE) was performed (McDonagh and Sheehan, 2006) on gill samples treated with menadione and GNP/menadione. Proteins 
$(150 \mu \mathrm{g})$ were focused in $7 \mathrm{~cm}$ nonlinear 3-10 IPG strips (Biorad) (Protean IEF Cell; BioRad). Strips were loaded on $12 \%$ gels, transferred to nitrocellulose as above, stained with BLOTFastStain $^{T M}$ (Geno Technology, St Louis, MO USA), scanned and compared with antiubiquitin blots.

Triplicate values (mean \pm SD) were compared by one-way analysis of variance (ANOVA). Post hoc tests (Newman-Keuls) discriminated between groups of means.

Variations in biomarkers are summarized (Table 1). Lysosomal membrane stability was only affected by menadione treatment $(\mathrm{p}<0.05)$. CAT activity increased in all treated digestive gland samples with GNP exposure showing highest significance $(\mathrm{p}<0.005)$. In mantle, GNP alone increased CAT activity whilst, in gill, only menadione did (Table 1).

Treatment- and tissue-specific ubiquitination differences were found (Table 1). Menadione alone increased ubiquitination in all tissues (McDonagh and Sheehan, 2006). Menadione/GNP decreased ubiquitination in all tissues compared with menadione alone. GNP alone increased ubiquitination in digestive gland more than menadione alone (Table1).

$1 \mathrm{DE}$ revealed treatment- and tissue-specific carbonylation patterns differing from ubiquitination (McDonagh and Sheehan, 2006). GNP alone induced greater carbonylation in gill (Table 1). Intriguingly, menadione/GNP reduced carbonylation below control levels in mantle (Table 1).

All gill biomarkers investigated showed no differences between control and GNP/ menadione (Table 1). However, 2DE comparison of gill GNP/menadione to menadione alone revealed lower ubiquitination in the former (Fig. 1).

Our results show that GNP may cause OS in bivalves, especially in digestive gland (higher ubiquitination, induction of CAT) but also in gill (higher ubiquitination and carbonylation). Co-exposure (GNP/menadione) appears to cancel out these effects (except for CAT activity in digestive gland). Recent ICP-MS measurements confirm high gold levels in 
digestive gland with modest levels in gill (not shown). We intend to extend this study by analyzing further indicators of OS.

\section{Acknowledgements}

We are funded by IRCSET and PRLTI of the Higher Education Authority.

\section{References}

Bradford, M.M. (1976). Analytical Biochemistry, 72, 248-254.

Casas, J.S., Castellano, E.E., Couce, M.D., Ellena, J., Sanchez, A., Sordo, J. et al. (2006). Journal Inorganic Biochemistry, 100, 1858-1860.

Claiborne, A. (1985). Handbook of Methods for Oxygen Radical Research. Ed.

Connor, E.E., Mwamuka, J., Gole, A., Murphy C.J., and Wyatt, M.D. (2005). Small, 1, 325327.

Lowe, D.M., Fossato, V.U., and Depledge, M.H. (1995). Marine Ecology Progress Series, 129, 189-196.

McDonagh, B., and Sheehan D. (2006). Aquatic Toxicology, 79, 325-333.

Moore, M.N. (2006). Environmental International, 32, 967-976.

Nel, A., Xia, T., Mädler, L., and Ning, L. (2006). Science, 311, 622-627

Tsoli, M., Kuhn, H., Brandau, W., Esche, H., and Schmid, G. (2005). Small, 1, 841-844.

Zhu, S., Oberdörster, E., and Haasch, M.L. (2006). Marine Environmental Perspective, 62, S1, S5-S9. 
Table 1.

Oxidative stress biomarkers in Mytilus edulis exposed to gold-citrate nanoparticles (GNP), menadione or $\mathrm{GNP} /$ menadione. (Mean $\pm \mathrm{SD}$; $\mathrm{n}=3$ /group). The $p$ values are reported for significant variations, ${ }^{*} p<0.05,{ }^{* *} p<0.005,{ }^{* * *} p<0.001$ indicate significant variations between groups of mean compared to control (post hoc comparison). Different letters indicate significant differences between groups of mean (post hoc comparison). Abbreviations: NS, not significant.

\begin{tabular}{|c|c|c|c|c|c|}
\hline Biomarkers & $\begin{array}{c}p- \\
\text { Value }\end{array}$ & Control & GNP & Menadione & GNP/menadione \\
\hline $\begin{array}{c}\text { NRRT } \\
\text { Haemolymph } \\
(\text { min })\end{array}$ & $\begin{array}{l}p< \\
0.05\end{array}$ & $\begin{array}{l}80.22 \pm \\
9.33^{\mathrm{ab}}\end{array}$ & $90.12 \pm 7.06^{\mathrm{a}}$ & $45.52 \pm 16.53^{\mathrm{c} *}$ & $61.84 \pm 11.59^{b c}$ \\
\hline $\begin{array}{c}\text { Catalase } \\
\text { activity } \\
\text { Digestive gland } \\
\text { (U/min/mg prot) }\end{array}$ & $\begin{array}{c}p< \\
0.005\end{array}$ & $2.29 \pm 0.39^{\mathrm{a}}$ & $5.64 \pm 0.86^{b_{* *}}$ & $3.99 \pm 0.30^{b *}$ & $4.65 \pm 1.03^{b_{*}}$ \\
\hline $\begin{array}{c}\text { Catalase } \\
\text { activity } \\
\text { Gill } \\
(\mathrm{U} / \mathrm{min} / \mathrm{mg} \text { prot }) \\
\end{array}$ & $\begin{array}{c}p< \\
0.001\end{array}$ & $1.43 \pm 0.28^{\mathrm{a}}$ & $1.94 \pm 0.22^{a}$ & $4.28 \pm 0.30^{b * \star \star}$ & $1.65 \pm 0.24^{\mathrm{a}}$ \\
\hline $\begin{array}{c}\text { Catalase } \\
\text { activity } \\
\text { Mantle } \\
\text { (U/min/mg prot) }\end{array}$ & $\begin{array}{c}p< \\
0.005\end{array}$ & $2.62 \pm 0.24^{\mathrm{a}}$ & $4.61 \pm 0.73^{b_{* *}}$ & $1.95 \pm 0.54^{\mathrm{a}}$ & $2.15 \pm 0.68^{a}$ \\
\hline $\begin{array}{l}\text { Ubiquitination } \\
\text { Digestive gland }\end{array}$ & $\begin{array}{c}p< \\
0.001\end{array}$ & $0.03 \pm 0.02^{\mathrm{a}}$ & $0.22 \pm 0.04^{b_{* \star \star}}$ & $0.15 \pm 0.02^{c_{* \star \star}}$ & $0.02 \pm 0.02^{\mathrm{a}}$ \\
\hline $\begin{array}{l}\text { Ubiquitination } \\
\text { Gill }\end{array}$ & $\begin{array}{l}p< \\
0.05\end{array}$ & $0.06 \pm 0.03^{a}$ & $0.23 \pm 0.09^{b_{*}}$ & $0.26 \pm 0.08^{b_{*}}$ & $0.08 \pm 0.04^{a}$ \\
\hline $\begin{array}{l}\text { Ubiquitination } \\
\text { Mantle }\end{array}$ & $\begin{array}{c}p< \\
0.001\end{array}$ & $0.45 \pm 0.05^{\mathrm{a}}$ & $0.39 \pm 0.01^{a}$ & $0.65 \pm 0.03^{b_{* *}}$ & $0.38 \pm 0.09^{a}$ \\
\hline $\begin{array}{l}\text { Carbonylation } \\
\text { Digestive gland }\end{array}$ & NS & $0.20 \pm 0.08$ & $0.14 \pm 0.08$ & $0.09 \pm 0.04$ & $0.03 \pm 0.03$ \\
\hline $\begin{array}{c}\text { Carbonylation } \\
\text { Gill }\end{array}$ & $\begin{array}{l}p< \\
0.05\end{array}$ & $0.11 \pm 0.03^{\mathrm{a}}$ & $0.25 \pm 0.11^{b_{*}}$ & $0.15 \pm 0.02^{\mathrm{ab}}$ & $0.11 \pm 0.04^{\mathrm{a}}$ \\
\hline $\begin{array}{c}\text { Carbonylation } \\
\text { Mantle }\end{array}$ & $\begin{array}{l}p< \\
0.05\end{array}$ & $0.32 \pm 0.04^{\mathrm{a}}$ & $0.36 \pm 0.20^{\mathrm{a}}$ & $0.21 \pm 0.09^{\mathrm{ab}}$ & $0.07 \pm 0.03^{b_{*}}$ \\
\hline
\end{tabular}




\section{Figure caption}

Fig.1. Two dimensional electrophoresis proteomic separations of gill proteins. (A) Menadione-exposed immunoblot with anti-ubiquitin. (B) GNP/menadione immunoblot with anti-ubiquitin. (C) and (D) corresponding Blot-Fast Stain.

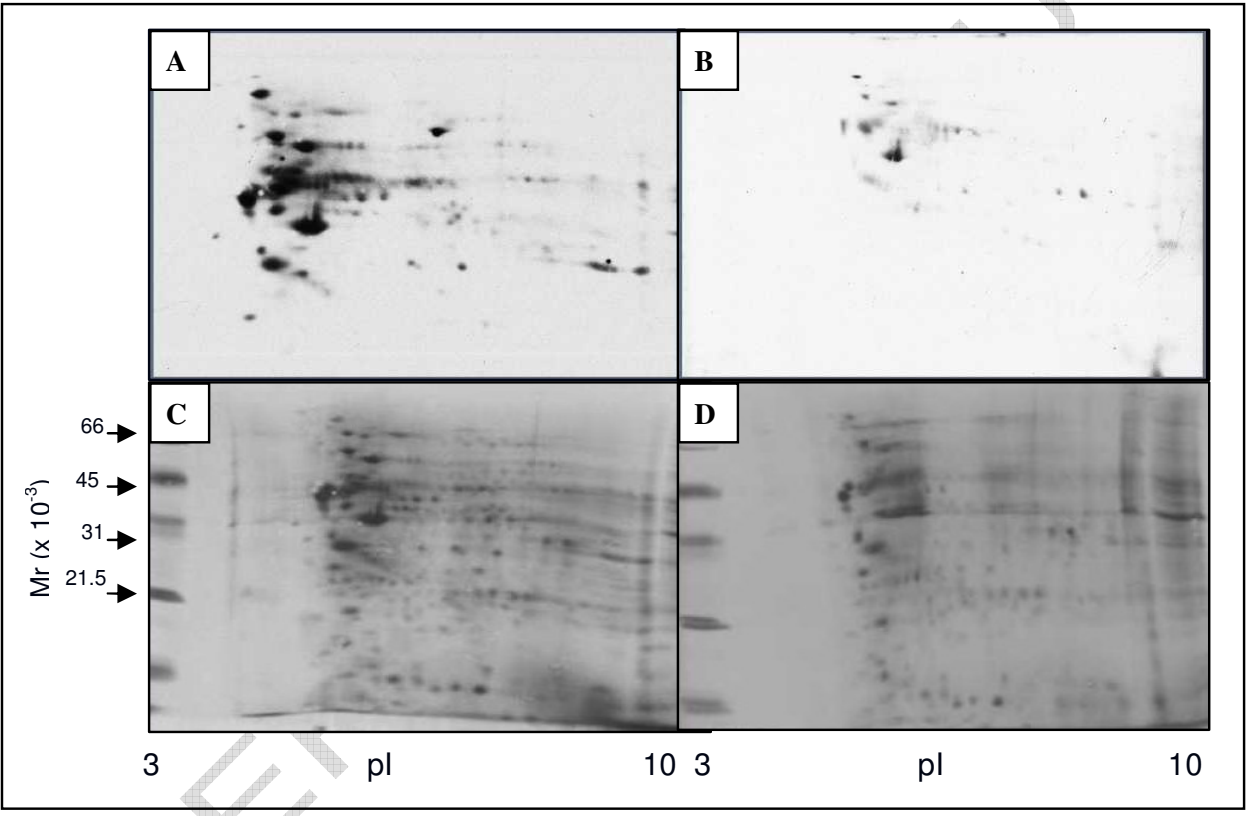

